\title{
Muscle injuries and strategies for improving their repair
}

\author{
Thomas Laumonier ${ }^{*}$ (D) and Jacques Menetrey
}

\begin{abstract}
Satellite cells are tissue resident muscle stem cells required for postnatal skeletal muscle growth and repair through replacement of damaged myofibers. Muscle regeneration is coordinated through different mechanisms, which imply cell-cell and cell-matrix interactions as well as extracellular secreted factors. Cellular dynamics during muscle regeneration are highly complex. Immune, fibrotic, vascular and myogenic cells appear with distinct temporal and spatial kinetics after muscle injury. Three main phases have been identified in the process of muscle regeneration; a destruction phase with the initial inflammatory response, a regeneration phase with activation and proliferation of satellite cells and a remodeling phase with maturation of the regenerated myofibers. Whereas relatively minor muscle injuries, such as strains, heal spontaneously, severe muscle injuries form fibrotic tissue that impairs muscle function and lead to muscle contracture and chronic pain. Current therapeutic approaches have limited effectiveness and optimal strategies for such lesions are not known yet. Various strategies, including growth factors injections, transplantation of muscle stem cells in combination or not with biological scaffolds, anti-fibrotic therapies and mechanical stimulation, may become therapeutic alternatives to improve functional muscle recovery.
\end{abstract}

Keywords: Skeletal muscle, Injury, Regeneration, Stem cell, Fibrosis, Scaffolds, Growth factors

\section{Introduction}

Human skeletal muscle is about $40 \%$ of the body mass and is formed by bundle of contractile multinucleated muscle fibers, resulting from the fusion of myoblasts. Satellite cells (SC) are skeletal muscle stem cell located between the plasma membrane of myofibers and the basal lamina. Their regenerative capabilities are essential to repair skeletal muscle after injury (Hurme and Kalimo 1992; Lipton and Schultz 1979) (Sambasivan et al. 2011; Dumont et al. 2015a). In adult muscles, SC are found in a quiescent state and represent, depending on species, age, muscle location, and muscle type, around 5 to $10 \%$ of skeletal muscle cells (Rocheteau et al. 2015). After injury, SC become activated, proliferate and give rise to myogenic precursor cells, known as myoblasts. After entering the differentiation process, myoblasts form new myotubes or fuse with damaged myofibers, ultimately mature in functional myofibers.

Skeletal muscle injuries can stem from a variety of events, including direct trauma such as muscle lacerations

\footnotetext{
* Correspondence: thomas.laumonier@unige.ch

Department of Orthopaedic Surgery, Geneva University Hospitals \& Faculty of Medicine, 4, Rue Gabrielle Perret-Gentil, 1211 Geneva 14, Switzerland
}

and contusions, indirect insults such as strains and also from degenerative diseases such as muscular dystrophies (Huard et al. 2002; Kasemkijwattana et al. 2000; Kasemkijwattana et al. 1998; Menetrey et al. 2000; Menetrey et al. 1999; Crisco et al. 1994; Garrett et al. 1984; Lehto and Jarvinen 1991; Jarvinen et al. 2005; Cossu and Sampaolesi 2007). Skeletal muscle can regenerate completely and spontaneously in response to minor injuries, such as strain. In contrast, after severe injuries, muscle healing is incomplete, often resulting in the formation of fibrotic tissue that impairs muscle function. Although researchers have extensively investigated various approaches to improve muscle healing, there is still no gold standard treatment.

This concise review provides a sight about the various phases of muscle repair and regeneration, namely degeneration, inflammation, regeneration, remodeling and maturation. We also give an overview of research efforts that have focused on the use of stem cell therapy, growth factors and/or biological scaffolds to improve muscle regeneration and repair. We also address the therapeutic potential of mechanical stimulation and of 
anti-fibrotic therapy to enhance muscle regeneration and repair.

\section{Review}

\section{Muscle healing process}

Skeletal muscle has a robust innate capability for repair after injury through the presence of adult muscle stem cells known as satellite cells (SC). The disruption of muscle tissue homeostasis, caused by injury, generates sequential involvement of various players around three main phases (Fig. 1).

- $(1,2)$ Degeneration/inflammation phase: characterized by rupture and necrosis of the myofibers, formation of a hematoma and an important inflammatory reaction.

- (3) Regeneration phase: phagocytosis of damaged tissue, followed by myofibers regeneration, leading to satellite cell activation.

- $(4,5)$ Remodeling phase: maturation of regenerated myofibers with recovery of muscle functional capacity (4) and also fibrosis and scar tissue formation (5).

\section{Muscle degeneration and inflammation}

Active muscle degeneration and inflammation occur within the first few days after injury. The initial event is necrosis of the muscle fibers, which is triggered by disruption of local homeostasis and particularly by unregulated influx of calcium through sarcolemma lesions (Tidball 2011). Excess in cytoplasmic calcium causes proteases and hydrolases activation that contribute to muscle damage and also causes activation of enzymes that drive the production of mitogenic substances for muscle and immune cells (Tidball 2005). After muscle degeneration, neutrophils are the first inflammatory cells infiltrating the lesion. A large number of proinflammatory molecules such as cytokines (TNF- $\alpha$, IL6), chemokine (CCL17, CCL2) and growth factors (FGF, HGF, IGF-I, VEGF; TGF- $\beta 1$ ) are secreted by neutrophils in order to create a chemoattractive microenvironment for other inflammatory cells such as monocytes and macrophages (Tidball 1995; Toumi and Best 2003). Two types of macrophages are identified during muscle regeneration (McLennan 1996), which appear sequentially

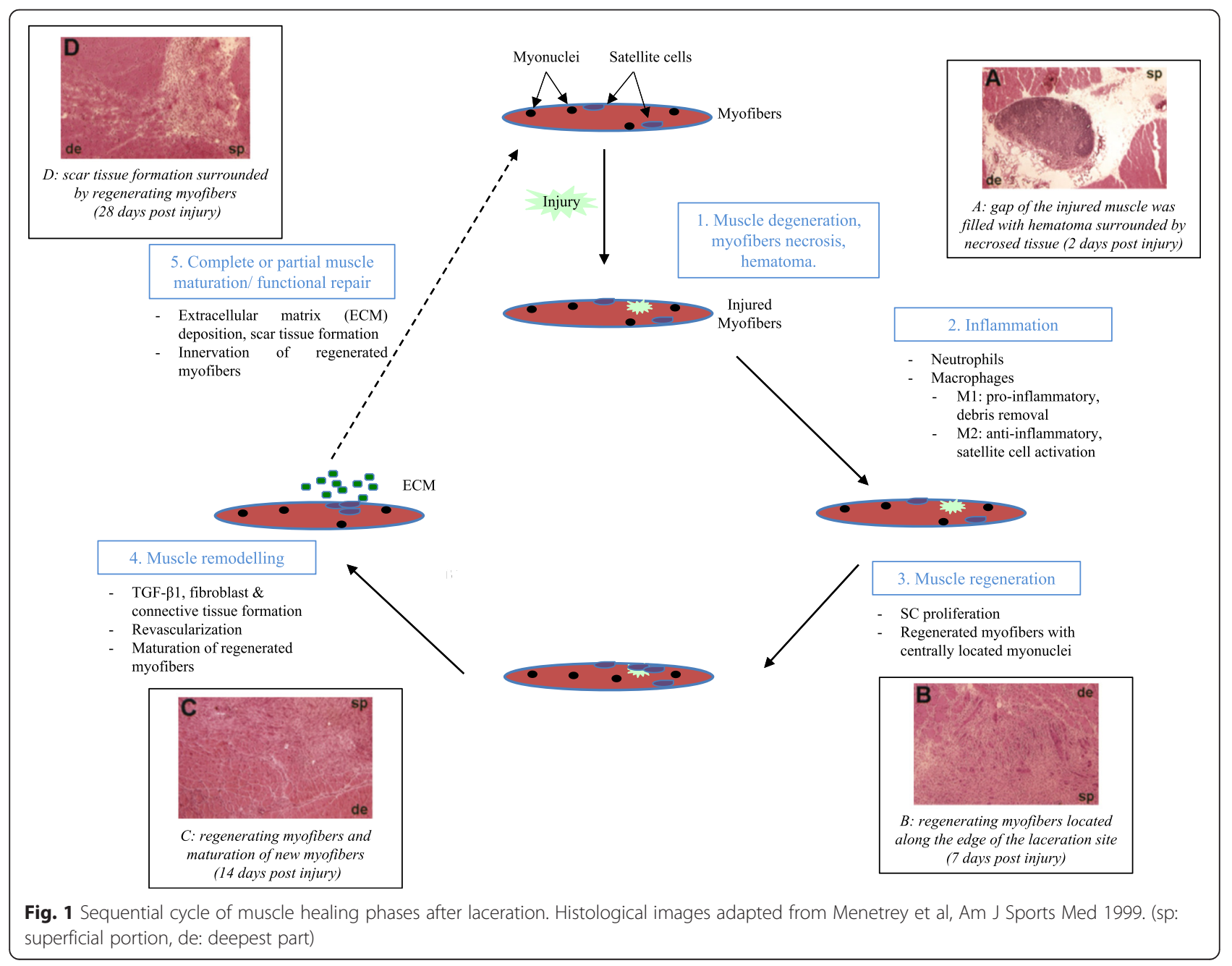


during muscle repair (Arnold et al. 2007). M1 macrophages, defined as pro-inflammatory macrophages, act during the first few days after injury,. contribute to cell lysis, removal of cellular debris and stimulate myoblast proliferation. Conversely, M2 macrophages, defined as anti-inflammatory macrophages, act 2 to 4 days after injury, attenuate the inflammatory response and favor muscle repair by promoting myotubes formation (Tidball and Wehling-Henricks 2007; Chazaud 2014; Chazaud et al. 2003). Macrophages, infiltrating injured muscle, are key players of the healing process (Zhao et al. 2016), able to participate in the muscle regeneration process or to favor fibrosis (Munoz-Canoves and Serrano 2015; Lemos et al. 2015).

\section{Muscle regeneration, remodeling and maturation}

Muscle regeneration usually starts during the first 4-5 days after injury, peaks at 2 weeks, and then gradually diminishes 3 to 4 weeks after injury. It's a multiple steps process including activation/proliferation of SC, repair and maturation of damaged muscle fibers and connective tissue formation. A fine balance between these mechanisms is essential for a full recovery of the contractile muscle function.

Muscle fibers are post-mitotic cells, which do not have the capacity to divide. Following an injury, damaged muscle fibers can't be repaired without the presence of adult muscle stem cells, the satellite cells (SC) (Relaix and Zammit 2012; Sambasivan et al. 2011). Following activation, SC proliferate and generate a population of myoblasts that can either differentiate to repair damaged fibers or, for a small proportion, self-renew to maintain the SC pool for possible future demands of muscle regeneration (Collins 2006; Dhawan and Rando 2005). SC cycle progression and cell fate determination are control by complex regulatory mechanisms in which, intrinsic and extrinsic factors are involved (Dumont et al. 2015a; Dumont et al. 2015b).

\section{Connective tissue/fibrosis}

Connective tissue remodeling is an important step of the regenerative muscle process. Rapidly after muscle injury, a gap is formed between damaged muscle fibers and filled with a hematoma. Muscle injuries can be clinically classified depending of the nature of the hematoma (size, location). Late elimination of the hematoma is known to delay skeletal muscle regeneration, to improve fibrosis and to reduce biomechanical properties of the healing muscle (Beiner et al. 1999). In rare complication, major muscle injuries may lead to the development of myositis ossificans that will impair muscle regeneration and repair (Beiner and Jokl 2002) (Walczak et al. 2015).

The presence of fibrin and fibronectin at the injury site, initiate the formation of an extracellular matrix that is rapidly invaded by fibroblasts (Darby et al. 2016; Desmouliere and Gabbiani 1995). Fibrogenic cytokines such as transforming growth factor $\beta 1$ (TGF- $\beta 1$ ) participate to excessive fibroblasts/myofibroblasts proliferation and to an increase in type I/III collagens, laminin and fibronectin production (Lehto et al. 1985). In its initial phase, the fibrotic response is beneficial, stabilizing the tissue and acting as a scaffold for myofibers regeneration. Nevertheless, an excessive collagen synthesis post injury, often result in an increase of scar tissue size over time that can prevent normal muscle function (Mann et al. 2011). Many growth factors are involved in the development of fibrosis, such as Connective Tissue Growth Factor (CTGF), Platelet-Derived Growth Factor (PDGF) or myostatin. TGF- $\beta 1$, by stimulating fibroblasts/myofibroblasts to produce extracellular proteins such as fibronectin and type I/III collagen, has been identified as the key element in this process (Mann et al. 2011),. Although fibroblasts are the major collagen-producing cells in skeletal muscle, TGF- $\beta 1$ have also an effect directly on myoblasts causing their conversion to myofibroblasts. Thus myoblasts initially acting to repair damaged myofibers, will produce significant level of collagen and will contribute to muscle fibrosis (Li and Huard 2002).

\section{Revascularization}

The restoration of the blood supply in the injured skeletal muscle is one of the first signs of muscle regeneration and is essential to its success. Without revascularization, muscle regeneration is incomplete and a significant fibrosis occurs (Best et al. 2012; Ota et al. 2011). After muscle trauma, blood vessels rupture induces tissue hypoxia at the injury site (Jarvinen et al. 2005). New capillaries formation quickly after injury is therefore necessary (Scholz et al. 2003) for a functional muscle recovery. Secretion of angiogenic factors such as vascular endothelial growth factor (VEGF) at the lesion site is important and several studies have shown that VEGF, by favoring angiogenesis, improve skeletal muscle repair (Deasy et al. 2009; Frey et al. 2012).

\section{Innervation}

Muscle repair is complete when injured myofibers are fully regenerated and become innervated. The synaptic contact between a motor neuron and its target muscle fiber, often take place at a specific site in the central region of myofibers, the neuromuscular junction (NMJ) (Wu et al. 2010). NMJ are essential for maturation and functional activity of regenerating muscles. Within 2-3 weeks after muscle damage, the presence of newly formed NMJ is observed in regenerative muscle (Rantanen et al. 1995; Vaittinen et al. 2001). 


\section{Strategies to improve muscle regeneration and repair Growth factors}

Growth factors play a variety of roles in the different stages of muscle regeneration (Grounds 1999; Menetrey et al. 2000). These biologically active molecules, synthetized by the injured tissue or by other cell types present at the inflammatory site, are release in the extracellular space and modulate the regenerative response (Table 1). Although hepatocyte growth factor (HGF), fibroblast growth factor (FGF) and platelet-derived growth factor (PDGF) are of interest because of their capacity to stimulate satellite cells (Sheehan et al. 2000; Allen and
Boxhorn 1989; Yablonka-Reuveni et al. 1990), insulin like growth factor-1 (IGF-I) appears to be of particular importance for the muscle regeneration process. IGF-I stimulates myoblasts proliferation and differentiation (Engert et al. 1996) and is implicated in the regulation of muscle growth (Schiaffino and Mammucari 2011). In a mouse model, direct injections of human recombinant IGF-I at two, five, and seven days after injury enhanced muscle healing in lacerated, contused, and strain-injured muscles (Menetrey et al. 2000; Kasemkijwattana et al. 2000). However, the efficacy of direct injection of recombinant proteins is limited by the high concentration of

Table 1 The role of growth factors in skeletal muscle regeneration

\begin{tabular}{|c|c|c|c|}
\hline $\begin{array}{l}\text { Growth } \\
\text { factors }\end{array}$ & Physiological effects, potential benefits & Shortcomings & Commentary \\
\hline IGF-1 & $\begin{array}{l}\text { - Essential for muscle growth during } \\
\text { development and regeneration. } \\
\text { - Promote myoblast proliferation and } \\
\text { differentiation in vitro (Huard et al. 2002) } \\
\text { - Hypertrophic effect of IGF-1 (Barton-Davis } \\
\text { et al. 1999) } \\
\text { - Serial injections of IGF-1 improve muscle } \\
\text { healing in vivo (Menetrey et al. 2000). } \\
\text { - Existence of a muscle specific isoform of } \\
\text { IGF-1 (mIGF-1) (Musaro et al. 1999; Musaro } \\
\text { et al. 2004) }\end{array}$ & $\begin{array}{l}\text { - Chemotactic for fibroblasts, increase } \\
\text { collagen production, enhance fibrosis } \\
\text { development }\end{array}$ & $\begin{array}{l}\text { - IGF-1 play a central role in the } \\
\text { enhancement of muscle regeneration- } \\
\text { - Anti-inflammatory actions of IGF-1 } \\
\text { (Mourkioti and Rosenthal 2005; Tidball } \\
\text { and Welc 2015) }\end{array}$ \\
\hline HGF & $\begin{array}{l}\text { - Promote myoblast proliferation and inhibit } \\
\text { myoblast differentiation (Anderson 2016; } \\
\text { Yin et al. 2013) } \\
\text { - Important role for satellite cell activation. } \\
\text { Balance between the activation of satellite } \\
\text { cells and their return to quiescence. } \\
\text { (Chazaud 2010) } \\
\text { - Recently, it was shown that a second set of } \\
\text { HGF production is crucial for inflammation } \\
\text { resolution after injury (Proto et al. 2015) }\end{array}$ & $\begin{array}{l}\text { - Injection of HGF into injured muscle } \\
\text { increased myoblast numbers but blocked } \\
\text { the regeneration process (Miller et al. 2000) }\end{array}$ & $\begin{array}{l}\text { - HGF is important during the early phase } \\
\text { of muscle regeneration, activate } \\
\text { satellite cells }\end{array}$ \\
\hline VEGF & $\begin{array}{l}\text { - Important signaling protein that favor } \\
\text { angiogenesis. } \\
\text { - Promote myoblast migration, proliferation } \\
\text { and survival. (Arsic et al. 2004) } \\
\text { - VEGF administration improves muscle } \\
\text { regeneration. (Messina et al. 2007; Deasy } \\
\text { et al. 2009) }\end{array}$ & $\begin{array}{l}\text { - Non regulated VEGF expression promote } \\
\text { aberrant angiogenesis and fibrosis in } \\
\text { skeletal muscle (Karvinen et al. 2011) }\end{array}$ & $\begin{array}{l}\text { - Importance of the proximity between } \\
\text { satellite cells and the microvasculature } \\
\text { during muscle } \\
\text { regeneration, role of VEGF }\end{array}$ \\
\hline FGF & $\begin{array}{l}\text { - Large family of mitogen involved in cell } \\
\text { growth and survival } \\
\text { - FGF-6 has a muscle specific expression, } \\
\text { stimulates satellite cell proliferation and } \\
\text { promotes myogenic terminal differentiation } \\
\text { (Floss et al. 1997) } \\
\text { - FGF-2 promote satellite cell proliferation } \\
\text { and inhibit myogenic differentiation } \\
\text { (Menetrey et al. 2000; Kastner et al. 2000) }\end{array}$ & - Stimulate fibroblast proliferation, & $\begin{array}{l}\text { - FGF signaling plays a key role in muscle } \\
\text { repair, blocking FGF signaling delay } \\
\text { muscle regeneration (Saera-Vila et al. 2016). }\end{array}$ \\
\hline TGF- $\beta 1$ & $\begin{array}{l}\text { - Key regulator of the balance between muscle } \\
\text { fibrosis and muscle regeneration } \\
\text { - Inhibits satellite cell proliferation and } \\
\text { differentiation in vitro }\end{array}$ & $\begin{array}{l}\text { - Excessive TGF } 1 \text { 1-induced deposition of } \\
\text { ECM at the site of injury, fibrosis (Garg } \\
\text { et al. 2015). }\end{array}$ & $\begin{array}{l}\text { - Anti fibrotic therapy by blocking } \\
\text { overexpression of TGF- } \beta 1 \text { improve muscle } \\
\text { regeneration. (Burks et al. 2011; Hwang et } \\
\text { al. 2016) }\end{array}$ \\
\hline $\begin{array}{l}\text { PDGF- } \\
\text { BB }\end{array}$ & $\begin{array}{l}\text { - PDGF isoforms can regulate myoblast } \\
\text { proliferation and differentiation in vitro } \\
\text { (Yablonka-Reuveni et al. 1990) } \\
\text { - PDGF-BB stimulates satellite cell } \\
\text { proliferation and inhibit their differentiation } \\
\text { (Charge and Rudnicki 2004) }\end{array}$ & - Potent mitogen for fibroblasts & $\begin{array}{l}\text { - Release from injured vessels and platelets, } \\
\text { PDGF stimulates early skeletal muscle } \\
\text { regeneration }\end{array}$ \\
\hline
\end{tabular}


the factor typically required to elicit a measurable effect. This is mainly due to the bloodstream's rapid clearance of these molecules and their relatively short biological half-lives. Gene therapy may be an effective method by which to deliver high, maintainable concentrations of growth factor to injured muscle (Barton-Davis et al. 1998; Barton et al. 2002; Musaro et al. 2001). Although IGF-I improved muscle healing, histology of the injected muscle revealed fibrosis within the lacerated site, despite high level of IGF-I production (Lee et al. 2000). Another growth factor, VEGF, by favoring angiogenesis, is known to enhance skeletal muscle repair (Deasy et al. 2009; Frey et al. 2012; Messina et al. 2007). By targeting simultaneously angiogenesis and myogenesis, it was shown that combined delivery of VEGF and IGF-I enhance muscle regenerative process (Borselli et al. 2010). In this direction, the use of platelet-rich plasma (PRP) is considered as a possible alternative approach based on the ability of autologous growth factors to improve skeletal muscle regeneration (Hamid et al. 2014; Hammond et al. 2009). Considered as safe products, autologous PRP injections are increasingly used in patients with sports-related injuries (Engebretsen et al. 2010). Nevertheless, a recent randomized clinical trial show no significant positive effects of PRP injections, as compared with placebo injections, in patients with muscle injuries, up to one year after injections (Reurink et al. 2014; Reurink et al. 2015). Customization of PRP preparation, as recently demonstrated by the use of TGF- $\beta 1$ neutralizing antibodies, is a promising alternative to promote muscle regeneration while significantly reducing fibrosis ( $\mathrm{Li}$ et al. 2016).

\section{Stem cells}

Transplantation of satellite cell-derived myoblasts has long been explored as a promising approach for treatment of skeletal muscle disorders. After an initial demonstration that normal myoblasts can restore dystrophin expression in $m d x$ mice (Partridge et al. 1989), clinical trials, in which allogeneic normal human myoblasts were injected intramuscularly several times in dystrophic young boys muscles, have not been successful (Law et al. 1990; Mendell et al. 1995). Even recently, despite clear improvement in methodologies that enhance the success of myoblast transplantation in Duchenne patients (Skuk et al. 2007), outcomes of clinical trials are still disappointing. These experiments have raised concerns about the limited migratory and proliferative capacities of human myoblasts, as well as their limited life span in vivo. It led to the investigations of other muscle stem cells sources that could overcome these limitations and outperform the success of muscle cell transplantation. Among all these non-satellite myogenic stem cells, human mesoangioblasts, human myogenic-endothelial cells and human muscle-derived CD133+ have shown myogenic potentials in vitro and in vivo (Sampaolesi et al. 2006; Zheng et al. 2007; Meng et al. 2014). The use of such myogenic progenitors cells for improving muscle healing may become an interesting therapeutic alternative (Tedesco and Cossu 2012; Tedesco et al. 2010; Chen et al. 2012). A first phase I/IIa clinical trial has recently demonstrated that intra arterial injections of human mesoangioblasts are safe but display only very limited clinical efficacy in Duchenne patients (Cossu et al. 2015).

\section{Scaffolds}

Myogenic precursor cell survival and migration is greatly increased by using appropriate scaffold composition and growth factor delivery (Hill et al. 2006) (Boldrin et al. 2007). Controlling the microenvironment of injected myogenic cells using biological scaffolds enhance muscle regeneration (Borselli et al. 2011). Ideally, using an appropriate extracellular matrix (ECM) composition and stiffness, scaffolds should best replicate the in vivo milieu and mechanical microenvironment (Gilbert et al. 2010) (Engler et al. 2006). A combination of stem cells, biomaterial-based scaffolds and growth factors may provide a therapeutic option to improve regeneration of injured skeletal muscles (Jeon and Elisseeff 2016).

\section{Anti-fibrotic therapy}

TGF- $\beta 1$ is expressed at high levels and plays an important role in the fibrotic cascade that occurs after the onset of muscle injury (Bernasconi et al. 1995; Li et al. 2004). Therefore, neutralization of TGF- $\beta 1$ expression in injured skeletal muscle should inhibit the formation of scar tissue. Indeed, the use of anti-fibrotic agents (ie decorin, relaxin, antibody against TGF- $\beta 1 \ldots$ ) that inactivate TGF- $\beta 1$ signaling pathways reduces muscle fibrosis and, consequently, improve muscle healing, leading to a near complete recovery of lacerated muscle (Fukushima et al. 2001; Li et al. 2007). Losartan, an angiotensin II receptor antagonist, neutralize the effect of TGF- $\beta 1$ and reduce fibrosis, making it the treatment of choice, since it already has FDA approval to be used clinically (Bedair et al. 2008; Park et al. 2012; Terada et al. 2013). Suramin, also approved by the FDA, blocks TGF- $\beta 1$ pathway and reduces muscle fibrosis in experimental model (Chan et al. 2003; Taniguti et al. 2011).

\section{Mechanical stimulation}

Mechanical stimulation may offer a simple and effective approach to enhance skeletal muscle regeneration. Stretch activation, mechanical conditioning but also massage therapy or physical manipulation of injured skeletal muscles have shown multiple benefit effects on muscle biology and function in vitro and in vivo (Tatsumi et al. 2001);(Best et al. 2012) (Crane et al. 2012; Kumar et al. 2002; Gilbert et al. 2010; Powell et al. 2002). Recently, Cezar and 
colleagues demonstrates that mechanical forces are as important biological regulators as chemicals and genes, and underlines the immense potential of developing mechanotherapies to treat muscle damage (Cezar et al. 2016). A recent study also demonstrated that a treatment based on ultrasound-guided intra-tissue percutaneous electrolysis (EPI technique) enhances the treatment of muscle injuries (Abat et al. 2015). Altogether, these results suggest that mechanical stimulation should be considered as a possible therapy to improve muscle regeneration and repair.

\section{Conclusions}

Skeletal muscle injuries are very frequently present in sports medicine and pose challenging problems in traumatology. Despite their clinical importance, the optimal rehabilitation strategies for treating these injuries are not well defined. After a trauma, skeletal muscles have the capacity to regenerate and repair in a complex and wellcoordinated response. This process required the presence of diverse cell populations, up and down-regulation of various gene expressions and participation of multiples growth factors. Strategies based on the combination of stem cells, growth factors and biological scaffolds have already shown promising results in animal models. A better understanding of the cellular and molecular pathways as well as a better definition of the interactions (cell-cell and cell-matrix) that are essential for effective muscle regeneration, should contribute to the development of new therapies in humans. In this direction, a recent paper from Sadtler et al demonstrated that specific biological scaffold implanted in injured mice muscles trigger a pro-regenerative immune response that stimulate skeletal muscle repair (Sadtler et al. 2016).

\section{Abbreviation}

CTGF, connective tissue growth factor; FGF, fibroblast growth factor; HGF, hepatocyte growth factor; IGF-I, insulin like growth factor-l; NMJ, neuromuscular junction; PDGF, platelet derived growth factor; PRP, platelet rich plasma; SC, satellite cells; TGF- $\beta 1$, transforming growth factor $\beta 1$; VEGF, vascular endothelial growth factor

\section{Competing interests}

The authors declare that they have no competing interests.

\section{Authors' contributions}

$T L$ and JM participated equally in drafting the manuscript. Both authors read and approved the final manuscript.

Received: 15 March 2016 Accepted: 15 July 2016

Published online: 22 July 2016

\section{References}

Abat F, Valles SL, Gelber PE, Polidori F, Jorda A, Garcia-Herreros S, Monllau JC, Sanchez-Ibanez JM (2015) An experimental study of muscular injury repair in a mouse model of notexin-induced lesion with EPI(R) technique. BMC Sports Sci Med Rehabil 7:7. doi:10.1186/s13102-015-0002-0

Allen RE, Boxhorn LK (1989) Regulation of skeletal muscle satellite cell proliferation and differentiation by transforming growth factor-beta, insulin-like growth factor I, and fibroblast growth factor. J Cell Physiol 138(2):311-315

Anderson JE (2016) Hepatocyte growth factor and satellite cell activation. Adv Exp Med Biol 900:1-25. doi:10.1007/978-3-319-27511-6_1
Arnold L, Henry A, Poron F, Baba-Amer Y, van Rooijen N, Plonquet A, Gherardi RK, Chazaud B (2007) Inflammatory monocytes recruited after skeletal muscle injury switch into antiinflammatory macrophages to support myogenesis. J Exp Med 204(5):1057-1069. doi:10.1084/jem.20070075

Arsic N, Zacchigna S, Zentilin L, Ramirez-Correa G, Pattarini L, Salvi A, Sinagra G, Giacca M (2004) Vascular endothelial growth factor stimulates skeletal muscle regeneration in vivo. Mol Ther 10(5):844-854

Barton ER, Morris L, Musaro A, Rosenthal N, Sweeney HL (2002) Muscle-specific expression of insulin-like growth factor I counters muscle decline in $\mathrm{mdx}$ mice. J Cell Biol 157(1):137-148

Barton-Davis ER, Shoturma DI, Musaro A, Rosenthal N, Sweeney HL (1998) Viral mediated expression of insulin-like growth factor I blocks the aging-related loss of skeletal muscle function. Proc Natl Acad Sci U S A 95(26):15603-15607

Barton-Davis ER, Shoturma DI, Sweeney HL (1999) Contribution of satellite cells to IGF-I induced hypertrophy of skeletal muscle. Acta Physiol Scand 167(4):301-305. doi:10.1046/j.1365-201x.1999.00618.x

Bedair HS, Karthikeyan T, Quintero A, Li Y, Huard J (2008) Angiotensin II receptor blockade administered after injury improves muscle regeneration and decreases fibrosis in normal skeletal muscle. Am J Sports Med 36(8):1548-1554. doi:10.1177/0363546508315470

Beiner JM, Jokl P (2002) Muscle contusion injury and myositis ossificans traumatica. Clin Orthop Relat Res (403 Suppl):S110-119

Beiner JM, Jokl P, Cholewicki J, Panjabi MM (1999) The effect of anabolic steroids and corticosteroids on healing of muscle contusion injury. Am J Sports Med 27(1):2-9

Bernasconi P, Torchiana E, Confalonieri P, Brugnoni R, Barresi R, Mora M, Cornelio F, Morandi L, Mantegazza R (1995) Expression of transforming growth factor-beta 1 in dystrophic patient muscles correlates with fibrosis. Pathogenetic role of a fibrogenic cytokine. J Clin Invest 96(2):1137-1144. doi:10.1172/JCl118101

Best TM, Gharaibeh B, Huard J (2012) Stem cells, angiogenesis and muscle healing: a potential role in massage therapies? Br J Sports Med. doi:10.1136/ bjsports-2012-091685

Boldrin L, Elvassore N, Malerba A, Flaibani M, Cimetta E, Piccoli M, Baroni MD, Gazzola MV, Messina C, Gamba P, Vitiello L, de Coppi P (2007) Satellite cells delivered by micro-patterned scaffolds: a new strategy for cell transplantation in muscle diseases. Tissue Eng 13(2):253-262

Borselli C, Storrie H, Benesch-Lee F, Shvartsman D, Cezar C, Lichtman JW Vandenburgh HH, Mooney DJ (2010) Functional muscle regeneration with combined delivery of angiogenesis and myogenesis factors. Proc Natl Acad Sci U S A 107(8):3287-3292. doi:10.1073/pnas.0903875106

Borselli C, Cezar CA, Shvartsman D, Vandenburgh HH, Mooney DJ (2011) The role of multifunctional delivery scaffold in the ability of cultured myoblasts to promote muscle regeneration. Biomaterials 32(34):8905-8914. doi:10.1016/j. biomaterials.2011.08.019

Burks TN, Andres-Mateos E, Marx R, Mejias R, Van Erp C, Simmers JL, Walston JD, Ward CW, Cohn RD (2011) Losartan restores skeletal muscle remodeling and protects against disuse atrophy in sarcopenia. Sci Transl Med 3(82):82ra37. doi:10.1126/scitransImed.3002227

Cezar CA, Roche ET, Vandenburgh HH, Duda GN, Walsh CJ, Mooney DJ (2016) Biologic-free mechanically induced muscle regeneration. Proc Natl Acad Sci U S A 113(6):1534-1539. doi:10.1073/pnas.1517517113

Chan YS, Li Y, Foster W, Horaguchi T, Somogyi G, Fu FH, Huard J (2003) Antifibrotic effects of suramin in injured skeletal muscle after laceration. J Appl Physiol 95(2):771-780. doi:10.1152/japplphysiol.00915.2002

Charge SB, Rudnicki MA (2004) Cellular and molecular regulation of muscle regeneration. Physiol Rev 84(1):209-238

Chazaud B (2010) Dual effect of HGF on satellite/myogenic cell quiescence. Focus on "High concentrations of HGF inhibit skeletal muscle satellite cell proliferation in vitro by inducing expression of myostatin: a possible mechanism for reestablishing satellite cell quiescence in vivo". Am J Physiol Cell Physiol 298(3):C448-C449. doi:10.1152/ajpcell.00561.2009

Chazaud B (2014) Macrophages: supportive cells for tissue repair and regeneration. Immunobiology 219(3):172-178. doi:10.1016/j.imbio.2013.09.001

Chazaud B, Sonnet C, Lafuste P, Bassez G, Rimaniol AC, Poron F, Authier FJ, Dreyfus PA, Gherardi RK (2003) Satellite cells attract monocytes and use macrophages as a support to escape apoptosis and enhance muscle growth. J Cell Biol 163(5):1133-1143. doi:10.1083/jcb.200212046

Chen CW, Corselli M, Peault B, Huard J (2012) Human blood-vessel-derived stem cells for tissue repair and regeneration. J Biomed Biotechnol 2012:597439. doi:10.1155/2012/597439 
Collins CA (2006) Satellite cell self-renewal. Curr Opin Pharmacol 6(3):301-306

Cossu G, Sampaolesi M (2007) New therapies for Duchenne muscular dystrophy: challenges, prospects and clinical trials. Trends Mol Med 13(12):520-526

Cossu G, Previtali SC, Napolitano S, Cicalese MP, Tedesco FS, Nicastro F, Noviello M, Roostalu U, Natali Sora MG, Scarlato M, De Pellegrin M, Godi C, Giuliani S, Ciotti F, Tonlorenzi R, Lorenzetti I, Rivellini C, Benedetti S, Gatti R, Marktel S, Mazzi B, Tettamanti A, Ragazzi M, Imro MA, Marano G, Ambrosi A, Fiori R, Sormani MP, Bonini C, Venturini M, Politi LS, Torrente Y, Ciceri F (2015) Intra-arterial transplantation of HLA-matched donor mesoangioblasts in Duchenne muscular dystrophy. EMBO Mol Med. doi:10.15252/emmm. 201505636

Crane JD, Ogborn DI, Cupido C, Melov S, Hubbard A, Bourgeois JM, Tarnopolsky MA (2012) Massage therapy attenuates inflammatory signaling after exercise-induced muscle damage. Sci Transl Med 4(119):119ra113. doi:10. 1126/scitranslmed.3002882

Crisco JJ, Jokl P, Heinen GT, Connell MD, Panjabi MM (1994) A muscle contusion injury model. Biomechanics, physiology, and histology. Am J Sports Med 22(5):702-710

Darby IA, Zakuan N, Billet F, Desmouliere A (2016) The myofibroblast, a key cell in normal and pathological tissue repair. Cell Mol Life Sci 73(6):1145-1157. doi: 10.1007/s00018-015-2110-0

Deasy BM, Feduska JM, Payne TR, Li Y, Ambrosio F, Huard J (2009) Effect of VEGF on the regenerative capacity of muscle stem cells in dystrophic skeletal muscle. Mol Ther 17(10):1788-1798. doi:10.1038/mt.2009.136

Desmouliere A, Gabbiani G (1995) Myofibroblast differentiation during fibrosis. Exp Nephrol 3(2):134-139

Dhawan J, Rando TA (2005) Stem cells in postnatal myogenesis: molecular mechanisms of satellite cell quiescence, activation and replenishment. Trends Cell Biol 15(12):666-673

Dumont NA, Bentzinger CF, Sincennes MC, Rudnicki MA (2015a) Satellite cells and skeletal muscle regeneration. Compr Physiol 5(3):1027-1059. doi:10.1002/ cphy.c140068

Dumont NA, Wang YX, Rudnicki MA (2015b) Intrinsic and extrinsic mechanisms regulating satellite cell function. Development 142(9):1572-1581. doi:10.1242/ dev. 114223

Engebretsen L, Steffen K, Alsousou J, Anitua E, Bachl N, Devilee R, Everts P, Hamilton B, Huard J, Jenoure P, Kelberine F, Kon E, Maffulli N, Matheson G, Mei-Dan O, Menetrey J, Philippon M, Randelli P, Schamasch P, Schwellnus M, Vernec A, Verrall G (2010) IOC consensus paper on the use of platelet-rich plasma in sports medicine. Br J Sports Med 44(15):1072-1081. doi:10.1136/ bjsm.2010.079822

Engert JC, Berglund EB, Rosenthal N (1996) Proliferation precedes differentiation in IGF-I-stimulated myogenesis. J Cell Biol 135(2):431-440

Engler AJ, Sen S, Sweeney HL, Discher DE (2006) Matrix elasticity directs stem cell lineage specification. Cell 126(4):677-689. doi:10.1016/j.cell.2006.06.044

Floss T, Arnold HH, Braun T (1997) A role for FGF-6 in skeletal muscle regeneration. Genes Dev 11(16):2040-2051

Frey SP, Jansen H, Raschke MJ, Meffert RH, Ochman S (2012) VEGF improves skeletal muscle regeneration after acute trauma and reconstruction of the limb in a rabbit model. Clin Orthop Relat Res 470(12):3607-3614. doi:10.1007/ s11999-012-2456-7

Fukushima K, Badlani N, Usas A, Riano F, Fu F, Huard J (2001) The use of an antifibrosis agent to improve muscle recovery after laceration. Am J Sports Med 29(4):394-402

Garg K, Corona BT, Walters TJ (2015) Therapeutic strategies for preventing skeletal muscle fibrosis after injury. Front Pharmacol 6:87. doi:10.3389/fphar. 2015.00087

Garrett WE Jr, Seaber AV, Boswick J, Urbaniak JR, Goldner JL (1984) Recovery of skeletal muscle after laceration and repair. J Hand Surg 9(5):683-692

Gilbert PM, Havenstrite KL, Magnusson KE, Sacco A, Leonardi NA, Kraft P, Nguyen NK, Thrun S, Lutolf MP, Blau HM (2010) Substrate elasticity regulates skeletal muscle stem cell self-renewal in culture. Science 329(5995):1078-1081. doi:10. 1126/science.1191035

Grounds MD (1999) Muscle regeneration: molecular aspects and therapeutic implications. Curr Opin Neurol 12(5):535-543

Hamid MS, Yusof A, Mohamed Ali MR (2014) Platelet-rich plasma (PRP) for acute muscle injury: a systematic review. PLoS One 9(2), e90538. doi:10.1371/ journal.pone.0090538

Hammond JW, Hinton RY, Curl LA, Muriel JM, Lovering RM (2009) Use of autologous platelet-rich plasma to treat muscle strain injuries. Am J Sports Med 37(6):1135-1142. doi:10.1177/0363546508330974
Hill E, Boontheekul T, Mooney DJ (2006) Designing scaffolds to enhance transplanted myoblast survival and migration. Tissue Eng 12(5):1295-1304

Huard J, Li Y, Fu FH (2002) Muscle injuries and repair: current trends in research. J Bone Joint Surg Am 84-A(5):822-832

Hurme T, Kalimo H (1992) Activation of myogenic precursor cells after muscle injury. Med Sci Sports Exerc 24(2):197-205

Hwang OK, Park JK, Lee EJ, Lee EM, Kim AY, Jeong KS (2016) Therapeutic effect of losartan, an angiotensin II type 1 receptor antagonist, on CCI(4)-induced skeletal muscle injury. Int J Mol Sci 17(2):227. doi:10.3390/ijms17020227

Jarvinen TA, Jarvinen TL, Kaariainen M, Kalimo H, Jarvinen M (2005) Muscle injuries: biology and treatment. Am J Sports Med 33(5):745-764. doi:10.1177/ 0363546505274714

Jeon OH, Elisseeff J (2016) Orthopedic tissue regeneration: cells, scaffolds, and small molecules. Drug Deliv Transl Res 6(2):105-120. doi:10.1007/s13346-015-0266-7

Karvinen H, Pasanen E, Rissanen TT, Korpisalo P, Vahakangas E, Jazwa A, Giacca M, Yla-Herttuala S (2011) Long-term VEGF-A expression promotes aberrant angiogenesis and fibrosis in skeletal muscle. Gene Ther 18(12):1166-1172. doi:10.1038/gt.2011.66

Kasemkijwattana C, Menetrey J, Somogyl G, Moreland MS, Fu FH, Buranapanitkit B, Watkins SC, Huard J (1998) Development of approaches to improve the healing following muscle contusion. Cell Transplant 7(6):585-598

Kasemkijwattana C, Menetrey J, Bosch P, Somogyi G, Moreland MS, Fu FH, Buranapanitkit B, Watkins SS, Huard J (2000) Use of growth factors to improve muscle healing after strain injury. Clin Orthop 370:272-285

Kastner S, Elias MC, Rivera AJ, Yablonka-Reuveni Z (2000) Gene expression patterns of the fibroblast growth factors and their receptors during myogenesis of rat satellite cells. J Histochem Cytochem 48(8):1079-1096

Kumar A, Chaudhry I, Reid MB, Boriek AM (2002) Distinct signaling pathways are activated in response to mechanical stress applied axially and transversely to skeletal muscle fibers. J Biol Chem 277(48):46493-46503. doi:10.1074/jbc. M203654200

Law PK, Bertorini TE, Goodwin TG, Chen M, Fang QW, Li HJ, Kirby DS, Florendo JA, Herrod HG, Golden GS (1990) Dystrophin production induced by myoblast transfer therapy in Duchenne muscular dystrophy. Lancet 336(8707):114-115

Lee C, Fukushima K, Usas A, Xin L, Pelinkovic D, Martinek V, Huard J (2000) Biological intervention based on cell and gene therapy to improve muscle healing after laceration. J Musculoskelet Res 4(4):256-277

Lehto MU, Jarvinen MJ (1991) Muscle injuries, their healing process and treatment. Ann Chir Gynaecol 80(2):102-108

Lehto M, Sims TJ, Bailey AJ (1985) Skeletal muscle injury-molecular changes in the collagen during healing. Res Exp Med 185(2):95-106

Lemos DR, Babaeijandaghi F, Low M, Chang CK, Lee ST, Fiore D, Zhang RH, Natarajan A, Nedospasov SA, Rossi FM (2015) Nilotinib reduces muscle fibrosis in chronic muscle injury by promoting TNF-mediated apoptosis of fibro/adipogenic progenitors. Nat Med 21(7):786-794. doi:10.1038/nm.3869

Li Y, Huard J (2002) Differentiation of muscle-derived cells into myofibroblasts in injured skeletal muscle. Am J Pathol 161(3):895-907. doi:10.1016/S0002-9440(10)64250-2

Li Y, Foster W, Deasy BM, Chan Y, Prisk V, Tang Y, Cummins J, Huard J (2004) Transforming growth factor-beta1 induces the differentiation of myogenic cells into fibrotic cells in injured skeletal muscle: a key event in muscle fibrogenesis. Am J Pathol 164(3):1007-1019

Li Y, Li J, Zhu J, Sun B, Branca M, Tang Y, Foster W, Xiao X, Huard J (2007) Decorin gene transfer promotes muscle cell differentiation and muscle regeneration. Mol Ther 15(9):1616-1622. doi:10.1038/s.mt.6300250

Li H, Hicks JJ, Wang L, Oyster N, Philippon MJ, Hurwitz S, Hogan MV, Huard J (2016) Customized platelet-rich plasma with transforming growth factor beta1 neutralization antibody to reduce fibrosis in skeletal muscle. Biomaterials 87:147-156. doi:10.1016/j.biomaterials.2016.02.017

Lipton BH, Schultz E (1979) Developmental fate of skeletal muscle satellite cells. Science 205(4412):1292-1294

Mann CJ, Perdiguero E, Kharraz Y, Aguilar S, Pessina P, Serrano AL, Munoz-Canoves P (2011) Aberrant repair and fibrosis development in skeletal muscle. Skelet Muscle 1(1):21. doi:10.1186/2044-5040-1-21

McLennan IS (1996) Degenerating and regenerating skeletal muscles contain several subpopulations of macrophages with distinct spatial and temporal distributions. J Anat 188(Pt 1):17-28

Mendell JR, Kissel JT, Amato AA, King W, Signore L, Prior TW, Sahenk Z, Benson S, McAndrew PE, Rice R, Nagaraja H, Stephens R, Lantry L, Morris GE, Burghes 
AH (1995) Myoblast transfer in the treatment of Duchenne's muscular dystrophy. N Engl J Med 333(13):832-838

Menetrey J, Kasemkijwattana C, Fu FH, Moreland MS, Huard J (1999) Suturing versus immobilization of a muscle laceration. A morphological and functional study in a mouse model. Am J Sports Med 27(2):222-229

Menetrey J, Kasemkijwattana C, Day CS, Bosch P, Vogt M, Fu FH, Moreland MS, Huard J (2000) Growth factors improve muscle healing in vivo. J Bone Joint Surg Br 82(1):131-137

Meng J, Chun S, Asfahani R, Lochmuller H, Muntoni F, Morgan J (2014) Human skeletal muscle-derived CD133(+) cells form functional satellite cells after intramuscular transplantation in immunodeficient host mice. Mol Ther 22(5): 1008-1017. doi:10.1038/mt.2014.26

Messina S, Mazzeo A, Bitto A, Aguennouz M, Migliorato A, De Pasquale MG, Minutoli L, Altavilla D, Zentilin L, Giacca M, Squadrito F, Vita G (2007) VEGF overexpression via adeno-associated virus gene transfer promotes skeletal muscle regeneration and enhances muscle function in $\mathrm{mdx}$ mice. FASEB $J$ 21(13):3737-3746. doi:10.1096/fj.07-8459com

Miller KJ, Thaloor D, Matteson S, Pavlath GK (2000) Hepatocyte growth factor affects satellite cell activation and differentiation in regenerating skeletal muscle. Am J Physiol Cell Physiol 278(1):C174-C181

Mourkioti F, Rosenthal N (2005) IGF-1, inflammation and stem cells: interactions during muscle regeneration. Trends Immunol 26(10):535-542. doi:10.1016/j.it. 2005.08.002

Munoz-Canoves P, Serrano AL (2015) Macrophages decide between regeneration and fibrosis in muscle. Trends Endocrinol Metab 26(9):449-450. doi:10.1016/j. tem.2015.07.005

Musaro A, McCullagh KJ, Naya FJ, Olson EN, Rosenthal N (1999) IGF-1 induces skeletal myocyte hypertrophy through calcineurin in association with GATA-2 and NF-ATC1. Nature 400(6744):581-585

Musaro A, McCullagh K, Paul A, Houghton L, Dobrowolny G, Molinaro M, Barton ER, Sweeney HL, Rosenthal N (2001) Localized Igf-1 transgene expression sustains hypertrophy and regeneration in senescent skeletal muscle. Nat Genet 27(2):195-200

Musaro A, Giacinti C, Borsellino G, Dobrowolny G, Pelosi L, Cairns L, Ottolenghi S, Cossu G, Bernardi G, Battistini L, Molinaro M, Rosenthal N (2004) Stem cell-mediated muscle regeneration is enhanced by local isoform of insulin-like growth factor 1. Proc Natl Acad Sci U S A 101(5):1206-1210

Ota S, Uehara K, Nozaki M, Kobayashi T, Terada S, Tobita K, Fu FH, Huard J (2011) Intramuscular transplantation of muscle-derived stem cells accelerates skeletal muscle healing after contusion injury via enhancement of angiogenesis. Am J Sports Med 39(9):1912-1922. doi:10.1177/ 0363546511415239

Park JK, Ki MR, Lee EM, Kim AY, You SY, Han SY, Lee EJ, Hong IH, Kwon SH, Kim SJ, Rando TA, Jeong KS (2012) Losartan improves adipose tissue-derived stem cell niche by inhibiting transforming growth factor-beta and fibrosis in skeletal muscle injury. Cell Transplant 21(11):2407-2424. doi:10.3727/ $096368912 \times 637055$

Partridge TA, Morgan JE, Coulton GR, Hoffman EP, Kunkel LM (1989) Conversion of mdx myofibres from dystrophin-negative to -positive by injection of normal myoblasts. Nature 337(6203):176-179

Powell CA, Smiley BL, Mills J, Vandenburgh HH (2002) Mechanical stimulation improves tissue-engineered human skeletal muscle. Am J Physiol Cell Physiol 283(5):C1557-C1565. doi:10.1152/ajpcell.00595.2001

Proto JD, Tang Y, Lu A, Chen WC, Stahl E, Poddar M, Beckman SA, Robbins PD, Nidernhofer L, Imbrogno K, Hannigan T, Mars WM, Wang B, Huard J (2015) NF-kappaB inhibition reveals a novel role for HGF during skeletal muscle repair. Cell Death Dis 6, e1730. doi:10.1038/cddis.2015.66

Rantanen J, Ranne J, Hurme T, Kalimo H (1995) Denervated segments of injured skeletal muscle fibers are reinnervated by newly formed neuromuscular junctions. J Neuropathol Exp Neurol 54(2):188-194

Relaix F, Zammit PS (2012) Satellite cells are essential for skeletal muscle regeneration: the cell on the edge returns centre stage. Development 139(16):2845-2856. doi:10.1242/dev.069088

Reurink G, Goudswaard GJ, Moen MH, Weir A, Verhaar JA, Bierma-Zeinstra SM, Maas M, Tol JL, Dutch Hamstring Injection Therapy Study I (2014) Platelet-rich plasma injections in acute muscle injury. N Engl J Med 370(26):2546-2547. doi:10.1056/NEJMc1402340

Reurink G, Goudswaard GJ, Moen MH, Weir A, Verhaar JA, Bierma-Zeinstra SM, Maas M, Tol JL, Dutch HITsl (2015) Rationale, secondary outcome scores and 1 -year follow-up of a randomised trial of platelet-rich plasma injections in acute hamstring muscle injury: the Dutch Hamstring Injection Therapy study. Br J Sports Med 49(18):1206-1212. doi:10.1136/bjsports-2014-094250

Rocheteau P, Vinet M, Chretien F (2015) Dormancy and quiescence of skeletal muscle stem cells. Results Probl Cell Differ 56:215-235. doi:10. 1007/978-3-662-44608-9_10

Sadtler K, Estrellas K, Allen BW, Wolf MT, Fan H, Tam AJ, Patel CH, Luber BS, Wang H, Wagner KR, Powell JD, Housseau F, Pardoll DM, Elisseeff JH (2016) Developing a pro-regenerative biomaterial scaffold microenvironment requires T helper 2 cells. Science 352(6283):366-370. doi:10.1126/science. aad9272

Saera-Vila A, Kish PE, Kahana A (2016) Fgf regulates dedifferentiation during skeletal muscle regeneration in adult zebrafish. Cell Signal 28(9):1196-1204. doi:10.1016/j.cellsig.2016.06.001

Sambasivan R, Yao R, Kissenpfennig A, Van Wittenberghe L, Paldi A, Gayraud-Morel B, Guenou H, Malissen B, Tajbakhsh S, Galy A (2011) Pax7-expressing satellite cells are indispensable for adult skeletal muscle regeneration. Development 138(17):3647-3656. doi:10.1242/dev.067587

Sampaolesi M, Blot S, D'Antona G, Granger N, Tonlorenzi R, Innocenzi A, Mognol P, Thibaud JL, Galvez BG, Barthelemy I, Perani L, Mantero S, Guttinger M, Pansarasa O, Rinaldi C, Cusella De Angelis MG, Torrente Y, Bordignon C, Bottinelli R, Cossu G (2006) Mesoangioblast stem cells ameliorate muscle function in dystrophic dogs. Nature 444(7119):574-579

Schiaffino S, Mammucari C (2011) Regulation of skeletal muscle growth by the IGF1-Akt/PKB pathway: insights from genetic models. Skelet Muscle 1(1):4. doi:10.1186/2044-5040-1-4

Scholz D, Thomas S, Sass S, Podzuweit T (2003) Angiogenesis and myogenesis as two facets of inflammatory post-ischemic tissue regeneration. Mol Cell Biochem 246(1-2):57-67

Sheehan SM, Tatsumi R, Temm-Grove CJ, Allen RE (2000) HGF is an autocrine growth factor for skeletal muscle satellite cells in vitro. Muscle Nerve 23(2): 239-245

Skuk D, Goulet M, Roy B, Piette V, Cote CH, Chapdelaine P, Hogrel JY, Paradis M, Bouchard JP, Sylvain M, Lachance JG, Tremblay JP (2007) First test of a "high-density injection" protocol for myogenic cell transplantation throughout large volumes of muscles in a Duchenne muscular dystrophy patient: eighteen months follow-up. Neuromuscul Disord 17(1):38-46. doi:10.1016/j.nmd.2006.10.003

Taniguti AP, Pertille A, Matsumura CY, Santo Neto H, Marques MJ (2011) Prevention of muscle fibrosis and myonecrosis in mdx mice by suramin, a TGF-beta1 blocker. Muscle Nerve 43(1):82-87. doi:10.1002/mus.21869

Tatsumi R, Sheehan SM, Iwasaki H, Hattori A, Allen RE (2001) Mechanical stretch induces activation of skeletal muscle satellite cells in vitro. Exp Cell Res 267(1):107-114. doi:10.1006/excr.2001.5252

Tedesco FS, Cossu G (2012) Stem cell therapies for muscle disorders. Curr Opin Neurol 25(5):597-603. doi:10.1097/WCO.0b013e328357f288

Tedesco FS, Dellavalle A, Diaz-Manera J, Messina G, Cossu G (2010) Repairing skeletal muscle: regenerative potential of skeletal muscle stem cells. J Clin Invest 120(1):11-19. doi:10.1172/JCl40373

Terada S, Ota S, Kobayashi M, Kobayashi T, Mifune Y, Takayama K, Witt M, Vadala G, Oyster N, Otsuka T, Fu FH, Huard J (2013) Use of an antifibrotic agent improves the effect of platelet-rich plasma on muscle healing after injury. J Bone Joint Surg Am 95(11):980-988. doi:10.2106/JBJS.L.00266

Tidball JG (1995) Inflammatory cell response to acute muscle injury. Med Sci Sports Exerc 27(7):1022-1032

Tidball JG (2005) Inflammatory processes in muscle injury and repair. Am J Physiol Regul Integr Comp Physiol 288(2):R345-R353. doi:10.1152/ajpregu. 00454.2004

Tidball JG (2011) Mechanisms of muscle injury, repair, and regeneration. Compr Physiol 1(4):2029-2062. doi:10.1002/cphy.c100092

Tidball JG, Wehling-Henricks M (2007) Macrophages promote muscle membrane repair and muscle fibre growth and regeneration during modified muscle loading in mice in vivo. J Physiol 578(Pt 1):327-336. doi:10.1113/jphysiol.2006. 118265

Tidball JG, Welc SS (2015) Macrophage-Derived IGF-1 Is a Potent Coordinator of Myogenesis and Inflammation in Regenerating Muscle. Mol Ther 23(7): 1134-1135. doi:10.1038/mt.2015.97

Toumi H, Best TM (2003) The inflammatory response: friend or enemy for muscle injury? Br J Sports Med 37(4):284-286

Vaittinen S, Lukka R, Sahlgren C, Hurme T, Rantanen J, Lendahl U, Eriksson JE, Kalimo H (2001) The expression of intermediate filament protein nestin as 
related to vimentin and desmin in regenerating skeletal muscle. J Neuropathol Exp Neurol 60(6):588-597

Walczak BE, Johnson CN, Howe BM (2015) Myositis Ossificans. J Am Acad Orthop Surg 23(10):612-622. doi:10.5435/JAAOS-D-14-00269

Wu H, Xiong WC, Mei L (2010) To build a synapse: signaling pathways in neuromuscular junction assembly. Development 137(7):1017-1033. doi:10. 1242/dev.038711

Yablonka-Reuveni Z, Balestreri TM, Bowen-Pope DF (1990) Regulation of proliferation and differentiation of myoblasts derived from adult mouse skeletal muscle by specific isoforms of PDGF. J Cell Biol 111(4):1623-1629

Yin H, Price F, Rudnicki MA (2013) Satellite cells and the muscle stem cell niche. Physiol Rev 93(1):23-67. doi:10.1152/physrev.00043.2011

Zhao W, Lu H, Wang X, Ransohoff RM, Zhou L (2016) CX3CR1 deficiency delays acute skeletal muscle injury repair by impairing macrophage functions. FASEB J 30(1):380-393. doi:10.1096/fj.14-270090

Zheng B, Cao B, Crisan M, Sun B, Li G, Logar A, Yap S, Pollett JB, Drowley L, Cassino T, Gharaibeh B, Deasy BM, Huard J, Peault B (2007) Prospective identification of myogenic endothelial cells in human skeletal muscle. Nat Biotechnol 25(9):1025-1034. doi:10.1038/nbt1334

\section{Submit your manuscript to a SpringerOpen ${ }^{\odot}$ journal and benefit from:}

- Convenient online submission

- Rigorous peer review

- Immediate publication on acceptance

- Open access: articles freely available online

- High visibility within the field

- Retaining the copyright to your article

Submit your next manuscript at $\gg$ springeropen.com 